GONSTITUTIONAL LAW: SUPREME GOURT DELINEATES THE RELATIONSHIP BETWEEN THE FOURTH AND FIFTH AMENDMENTS

In Schmerber v. California the Supreme Court reaffirmed the admissibility of blood test evidence procured without consent of the accused. Rejecting petitioner's fourth and fifth amendment claims, the Court utilized a refined definition of the privilege against self-incrimination in determining the reasonableness of intracorporeal search and seizure. Moreover, the approach taken by the majority arguably presages the demise of the mere evidence rule.

$T$ HE CONSTITUTIONAL standards governing the extent to which the government, in search of evidence, may intrude into the body of a criminally accused have not been defined clearly. Until the fourth and fifth amendments became specifically applicable to the states, ${ }^{1}$ the constitutionality of intracorporeal searches was measured in terms of the general due process standards of the fourteenth amendment. ${ }^{2}$ However, the imposition of the particular mandates of the fourth and fifth amendments produced a problematical effect in light of the Supreme Court's failure to develop certain substantive aspects of these amendments. ${ }^{3}$ This failure may be due at least in part to the confusion inherent in the line of decisions derived from Boyd $v$. United States. ${ }^{4}$ In that case the Supreme Court held that the search

\footnotetext{
1 Malloy v. Hogan, 378 U.S. 1 (1964), applied fifth amendment self-incrimination standards to the states and Mapp v. Ohio, 367 U.S. 643 (1961), required them to conform to the fundamental criteria of the fourth amendment.

${ }^{2}$ See Breithaupt v. Abram, 352 U.S. 432 (1957); Rochin v. California, 342 U.S. 165 (1952).

${ }^{3}$ The Supreme Court has consistently refused to grant certiorari in federal border search cases involving searches where the fourth and fifth amendments arguably were applicable. See Lane v. United States, 321 F.2d 573 (5th Cir. 1963), cert. denied, 377 U.S. 936 (1964); Bible v. United States, 314 F.2d 106 (9th Cir.), cert. denied, 375 U.S. 862 (1963); Murgia v. United States, 285 F.2d 14 (9th Cir. 1960), cert. denied, 366 U.S. 977 (1961); Blackford v. United States, 247 F.2d 745 (9th Gir. 1957), cert. denied, 356 U.S. 914 (1958); United States v. Michel, 158 F. Supp. 34 (S.D. Tex. 1957), aff'd sub nom. King v. United. States, 258 F.2d 754 (5th Cir. 1958), cert. denied, 359 U.S. 939 (1959); Note, 115 U. PA. L. REv. 276 (1966).

- 116 U.S. 616 (1886). Another possible explanation for the Court's hesitancy lies in the fact that the federal cases, involving "border searches," required decisions as to whether such searches might be justified notwithstanding the employment of less stringent standards of protection than otherwise required under the fourth and fifth amendments. See note 65 infra.
} 
for and seizure of evidence within an accused's possession might well result in compelling the accused to be a witness against himself, thus violating his privilege against self-incrimination. ${ }^{5}$ If this were true, reasoned that Court, then the search itself must be unreasonable $a b$ initio, and therefore a violation of the fourth amendment. ${ }^{6}$ Since that decision, the scope of the fifth amendment and its relationship to the fourth have been singularly muddled areas of constitutional law. 7 Recent Supreme Court scrutiny of certain phases of the fourth ${ }^{8}$ and fifth amendments ${ }^{9}$ made inevitable a redefinition of the relationship between the two amendments. The opportunity for clarification was presented in Schmerber $v$. California, ${ }^{10}$ where the Court held that the introduction into evidence of a blood sample taken over the accused's verbal protest neither forced him to be a witness against himself ${ }^{11}$ nor constituted an unreasonable search and seizure of his person.12 Implicit in the Court's analysis of the fourth and fifth amendments was a rejection of the "mere evidence" rule as a fourth amendment concept governing the type of evidence which may be acquired in a search. ${ }^{13}$

The petitioner in Schmerber was arrested for driving while intoxicated. $^{14}$ Pursuant to the arresting officer's direction, a hospital physician extracted a sample of the petitioner's blood for analysis despite the latter's objections. ${ }^{15}$ At trial, the results of the blood analysis

116 U.S. at 633 .

- Id. at 633, 634-35.

'See, e.g., Corwin, The Supreme Court's Construction of the Self-Incrimination Clause, 29 MicH. L. REv. 1, 13-27 (1930); Shellow, The Continuing Vitality of the Gouled Rule: The Search for and Seizure of Evidence, 48 MARQ. L. REv. 172 (1964); Comment, 66 Colum. L. REv. 355, 359-70 (1966); Note, 54 Gro. L.J. 593 (1966); Comment, 13 U.C.L.A.L. REv. 857 (1966); Comment, 20 U. ChI. L. REv. 319 (1953).

${ }^{8}$ See Ker v. California, 374 U.S. 23 (1963); Mapp v. Ohio, 367 U.S. 643 (1961).

- See Miranda v. Arizona, 384 U.S. 436 (1966); Malloy v. Hogan, 378 U.S. 1 (1964); Murphy v. Waterfront Comm'n, 378 U.S. 52 (1964); cf. Escobedo v. Illinois, 378 U.S. 478 (1964).

10384 U.S. 757 (1966).

11 Id. at 765 .

12 Id. at 772 .

${ }^{13}$ See notes 101-08 infra and accompanying text.

14 Petitioner's prosecution was instituted pursuant to CAL. VEHICLE CODE \$23102 (a), which makes it a misdemeanor to drive while under the influence of intoxicating liquor.

${ }^{15}$ Discovery of petitioner's intoxicated condition was occasioned by his having been injured in an accident. Indicia of intoxication which had been observed by the investigating officer were still noticeable two hours later at the hospital where petitioner was actually arrested. The officer then requested that petitioner submit to a blood test. On the advice of counsel, he refused, but the testing was nevertheless carried out by the examining physician at the arresting officer's direction. 384 U.S. at 758-59, 768-69. 
were admitted into evidence over the petitioner's claim that the blood was obtained by an unreasonable search and seizure and that the introduction of the results against him violated his privilege against self-incrimination. The conviction was affirmed on appeal ${ }^{16}$ and the Supreme Court granted certiorari ${ }^{17}$ to assess the limitations upon the blood extraction procedure imposed through the extension of fourth and fifth amendment standards to the states. ${ }^{18}$ A majority of the Court denied petitioner's self-incrimination claim because the blood test evidence was not acquired by compelling him to communicate. ${ }^{19}$ Having determined that the fifth amendment did not preclude obtaining this evidence from within the accused's body, the majority viewed the fourth amendment as requiring that there be sufficient cause to seek the desired evidence and that reasonable procedures be utilized to obtain it. ${ }^{20}$ The Court concluded that the petitioner's visible manifestations of intoxication constituted suffcient cause for the arresting officer to invoke a commonplace, hygienic procedure to procure evidence of intoxication. ${ }^{21}$

Evidently, the petitioner offered no physical resistance to the blood test. Even if he had done so, however, the Court intimated that its constitutional analysis would have been unaffected by this additional factor unless improper or undue force had been used to reduce the petitioner to submission. See id. at 760 n.4.

20 See $i d$. at 759 n.s.

27382 U.S. 971 (1966).

${ }^{18}$ Schmerber v. California, 384 U.S. 757, 759 (1966). In Breithaupt v. Abram, 352 U.S. 432, 434 (1957), the Court had denied petitioner's fourth and fifth amendment claims on the ground that the amendments were inapplicable to defendants tried by the state. See Note, 17 Hastings L.J. 139 (1965).

${ }^{20} 384$ U.S. at 765 (Brennan, Clark, and White, JJ.), 772 (Harlan and Stewart, JJ., concurring). Mr. Justice Black wrote a dissenting opinion in which he asserted that the result reached by the majority was illogical and indefensible because testimony obtained from the analysis of forcibly extracted blood was just as "communicative" or "testimonial" as the compelled production of incriminatory papers which the majority had held to be within the privilege. Id. at 775, 778 (dissenting opinion). By refusing to recognize the similarity between the two situations, the majority had, in Mr. Justice Black's view, deviated from the mandate of prior cases which required the privilege to be hiberally construed. Id. at 775-78.

Of the four dissenters, only Mr. Chief Justice Warren relied solely upon a due process objection, citing his dissenting opinion in Breithaupt v. Abram, 352 U.S. 432 (1957). See note 28 infra. The other members of the minority, Black, Douglas, and Fortas, JJ., relied upon both self-incrimination and due process arguments. Id. at $773-78,778,779$.

$20 I d$. at 768 .

21 Id. at 770-72. The Court also denied petitioner's due process claim on the authority of Breithaupt v. Abram, 352 U.S. 432 (1957). 384 U.S. at 759-60. See notes 27-29 infra and accompanying text.

In addition, the Court summarily rejected petitioner's assertion that he had been denied his sixth amendment right to counsel. The Court reasoned that since the fifth amendment did not protect petitioner from being forced to submit to the blood test, 


\section{Due Process}

The first Supreme Court case involving a state's attempt to acquire evidence from within a suspect's body was Rochin $v$. Califormia. ${ }^{22}$ In that case, police officers illegally entered the accused's home and attempted to force him to regurgitate pills which had been swallowed upon the officers' appearance. Failing this, the suspect was taken to a hospital where a "stomach pump" was utilized to recover morphine capsules. In reversing Rochin's conviction for illegal possession of narcotics, the Supreme Court characterized the police action as conduct which "shocks the conscience,"23 violating the community's "sense of fair play," 24 and therefore held that the petitioner's right to due process under the fourteenth amendment had been abridged. ${ }^{25}$ In dictum the Court analogized the procurement of evidence from within the body to coerced confessions, stating that it would not take the inconsistent position that "in order to convict a man the police cannot extract by force what is in his mind "but can extract what is in his stomach."'26

The efficacy of Rochin was diminished, however, by the Court's subsequent decision in Breithaupt $v$. Abram. ${ }^{27}$ There the Court held that a blood test conducted upon an unconscious driver was not a violation of due process since blood tests were ordinary, everyday occurrences which did not offend the community's "sense of decency and fairness." 28 Rochin was distinguished on the grounds that there

the fact that he was compelled to do so against his will and contrary to the advice of counsel was not a denial of counsel. 384 U.S. at 765-66. See Ruffin, Intoxication Tests and the Bill of Rights: A New Look, 2 CALIF. WeSTERN L. REv. 1, 99 (1966).

22342 U.S. 165 (1952).

ss Id. at 172. This criterion failed to survive as a test of due process. In Irvine v. California, 347 U.S. 128, 133-34 (1954), the Court held that a standard which attempted to discriminate between "mild" and "serious" shocks to the conscience was too indefinite to offer protection for constitutional rights.

24342 U.S. at 173.

$25 I d$. at 173-74.

$20 \mathrm{Id}$. at 173.

27352 U.S. 432 (1957).

${ }^{28} \mathrm{Id}$. at 436. Mr. Chief Justice Warren dissented on the ground that the nature of the tests, invasion into the body, was the same in both Rochin and Breithaupt. He argued that both stomach pump and blood tests are common and accepted ways of obtaining body fluids and both tests had been performed by hospital physicians. The only difference was the "personal reaction" of the majority to the tests, which should not be a sufficient grounds for denying the accused his constitutional rights. Id. at 441-42. Mr. Justice Douglas believed-that the majority in Breithaupt sanctioned an assault by the police upon the accused. Id. at 444 . Due process, in his opinion, was violated by the compelled extraction of body fluids as well as by "involuntary extraction of words from the accused's lips ...." Id. at 443 . The dissents in 
the entire course of police action, beginning with the illegal entry into the accused's home, was wrongful and the brutality of police coerciveness a violation of due process. ${ }^{29}$ Prior to Schmerber $v$. California these two cases provided the only Supreme Court standards for constitutional limitations upon intrusions into the body. ${ }^{30}$

\section{SELF-INCRIMINATION}

Before the adoption of the fifth amendment, a privilege against self-incrimination was well established in the English common law..$^{31}$ Under English practice, the privilege was merely an evidentiary rule ${ }^{32}$ which prohibited the admission of evidence obtained by the "employment of legal process to extract from a person's own lips an admission of guilt, which would thus take the place of other evidence." 33 The framers of the fifth amendment apparently intended to incorporate this historical definition into the amendment to protect a defendant from being compelled to give testimony against himself in a criminal proceeding. ${ }^{34}$ The Supreme Court, however,

Schmerber were predicated to a large degree upon these dissents in Breithaupt. Schmerber v. California, 384 U.S. 757, 772 (1966) (Warren, C.J., dissenting); id. at 778 (Douglas, J., dissenting); id. at 779 (Fortas, J., dissenting). See Note, 35 FordhaM L. REV. 131 (1966).

${ }^{29}$ 352. U.S. at 435-36. A few commentators have indicated that Rochin may still be authority for the proposition that a compulsory "stomach pump" is per se violative of due process. See Note, 35 FordinM L. Rev. 131, 136-37 (1966); Note, 115 U. PA. L. REv. 276, 280-83 (1966). However, the case law, as evolved by the courts of appeals in the context of border searches, is otherwise. See, e.g., Blefare v. United States, 362 F.2d 870 (9th Cir. 1966), and cases cited therein at 875 .

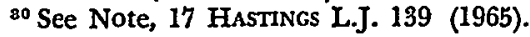

${ }^{31}$ See generally Corwin, supra note 7, at 2-12; Morgan, The Privilege Against SelfIncrimination, 34 MINN. L. Rev. 1 (1949); 8 WIGMORE, Evidence \$\$2250.51 (McNaughtou rev. ed. 1961) [hereinafter cited as WIGMORE].

${ }^{22}$ See Twining v. New Jersey, 211 U.S. 78, 106 (1908); Brown v. Walker, 161 U.S. 591, 597 (1896); SutherLAND, Notes ON UNITEd STATES CoNSTITUTION 639 (1904); Griswold, The Right to be Let Alone, 55 Nw. U.L. Rev. 216, 223 (1960).

ss 8 WIGMORE $\$ 2263$, at 378 . (Emphasis in original.)

${ }^{86}$ The precise intent of the amendment's authors is unclear. The language itself"No person ... shall be compelled in any criminal case to be a witness against him. self," U.S. CoNST. amend. V-suggests an application limited to criminal proceedings. Miranda v. Arizona, 384 U.S. 486, 526-27 (1966) (White, J., dissenting); 8 Wigmore $\S 2252$, at 324. See Brown v. Mississippi, 297 U.S. 285 (1936). But see Corwin, supra note 7 , at 12 .

The impetus for the development of the privilege against self-incrimination arose from opposition to the oath ex officio employed by the English Court of the Star Chamber in the sixteenth and seventeenth centuries. Under that oath, an individual could be questioned concerning any of his activities or beliefs and then be convicted on the basis of such testimony. Grisword, THE FIFTH AMENDMENT TOdAx 2-7 (1955).

The Puritan heritage of persecution under the oath and the Royal Governors' use of the prerogative courts to uncover sedition among the colonists resulted in the 
has not been content to confine the protections of the privilege to those situations covered by the literal words of the Constitution. Rather, the Court has viewed the privilege in terms of the broad policies it seeks to effectuate ${ }^{35}$ and has applied it to protect witnesses appearing before grand juries, legislative committees, and judicial bodies ${ }^{36}$ and persons detained in police custody. ${ }^{37}$ While it has thus been clear that an accused's oral responses may be privileged, whether non-verbal evidence may also be elicited has been the subject of controversy. ${ }^{38}$ The first Supreme Court case to consider the constitutional implications of the privilege, Boyd $v$. United States, ${ }^{39}$ involved compelling the defendant to produce incriminating papers

appearance of the privilege in colonial and federal constitutions. Pittman, The Colonial and Constitutional History of the Privilege Against Self-Incrimination in America, 21 VA. L. Rev. 763, 769-89 (1935). See generally Mayers, ShaLl WE AMEND THE FIFTH AMENDMENT? 9-19, 218-23 (1959); 8 WIGMORE \$§ 2250-51; Corwin, supra note 7, at 2-12; Fortas, The Fifth Amendment: Nemo Tenetur Prodere Seipsum, 25 Cu.Ev. B.J. 91, 96-97 (1954); Morgan, supra note 31, at 1-23.

There is some evidence from the brief discussion of the amendment at the time of its adoption that at least some of the supporters of the privilege thought of it in terms of the privilege against coerced confessions obtained by physical force in extrajudicial proceedings. See Pittman, supra at 788. Both the judicial and extrajudicial aspects of the privileges were finally integrated in Escobedo v. Illinois, 378 U.S. 478 (1964), and Miranda v. Arizona, 384 U.S. 436 (1966).

${ }^{85}$ The most recent enumeration of the general goals of the self-incrimination privilege is found in Murphy v. Waterfront Comin'n, 378 U.S. 52 (1964), where the Court stated that the privilege "reflects many of our fundamental values and most noble aspirations: our unwillingness to subject those suspected of crime to the cruel trilemma of self-accusation, perjury or contempt; our preference for an accusatorial rather than an inquisitorial system of criminal justice; our fear that self-incriminating statements will be elicited by inhumane treatment and abuses; our sense of fair play which dictates 'a fair state-individual balance by requiring the government to leave the individual alone until good cause is shown for disturbing him and by requiring the government in its contest with the individual to slsoulder the entire load'; our respect for the inviolability of the luuman personality and of the rigbt of each individual 'to a .. . private life'; our distrust of self-deprecatory statements; and our realization that the privilege, while sometimes 'a shelter to the guilty,' is often 'a protection to the innocent." "Id. at 55. See generally McNaughton, The Privilege Against Self-Incrimination, 51 J. CRIM. L., C. \& P.S. 138 (1960).

${ }^{30}$ Malloy v. Hogan, 378 U.S. I (1964) (referee appointed by state court); Murphy v. Waterfront Comm'n, 378 U.S. 52 (1964) (bistate body established under interstate compact); Quinn v. United States, 349 U.S. 155 (1955) (legislative committee); McCarthy v. Arndstein, 266 U.S. 34 (1924) (judicial proceedings concerning bankruptcy); Counselman v. Hitchcock, 142 U.S. 547 (1892) (grand jury); Comment, 65 ColvM. L. REv. 681-82 (1965); Comment, 1967 Duke L.J. 97, 111-20.

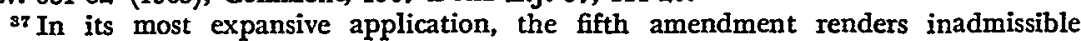
statements procured during interrogation from a suspect unaware of his right to remain silent and to have the assistance of counsel. See Miranda v. Arizona, 384 U.S. 436 (1966).

${ }^{38}$ See, e.g., Comment, 66 Colum. L. REv. 355, $359-70$ (1966); Comment, 13 U.C.L.A.L. REv. 857 (1966).

a9 116 U.S. 616 (1886). 
in court. ${ }^{40}$ In reversing the defendant's conviction as violative of the fourth and fifth amendments, Boyd expanded the privilege to protect forms of self-incrimination other than those involving compelled testimony: the Court was unable to find any significant difference between compelling the production of incriminating papers and exacting a confession of guilt from the witness stand.41 The thrust of the Court's analogy indicated that as a general proposition the accused could not be forced to be the source of incriminating evidence. ${ }^{42}$

Nevertheless, the full implication of the Boyd analogy was tacitly rejected by a later Court as "an extravagant extension of the 5th Amendment."43 Holt $v$. United States ${ }^{44}$ involved a contention that the Government's compelling a defendant to model a coat found at the scene of the crime forced him to give evidence against himself. ${ }^{45}$ However, the Court dismissed this objection by reasoning that the privilege against self-incrimination was desigued merely to prohibit the extortion of communications from an accused and not to preclude the prosecution's use of "the body as evidence when it may be material."46

On the basis of the Holt decision, lower courts subsequently formulated a distinction between "testimonial" and "real" evidence obtained from an accused in order to determine the applicability of the privilege. ${ }^{47}$ The operative assumption was that only the former

\footnotetext{
${ }^{0}$ The statute which was held unconstitutional in Boyd, Act of June 22, 1874, ch. $391, \S 5,18$ Stat. 186, allowed district courts to issue subpoenas compelling the production of papers allegedly containing evidence of contraband activity in importing. If the accused did not produce the papers, the allegations were taken as confessed.

1116 U.S. at $633-37$.

12 Id. at $633,634-35,637$. The Boyd Court stated, however, that the self-incrimination privilege was inapplicable where instrumentalities, contraband, or stolen property were seized because, in such cases, the state had a prior possessory interest. Id. at 623-24. See note 76 infra.

${ }^{13}$ Holt v. United States, 218 U.S. 245, 252-53 (1910).

4 218 U.S. 245 (1910).

"5 Brief for Plaintiff in Error, Holt v. United States, 54 L. Ed. 1021, 1025 (1910); see 218 U.S. at $252-53$.

¿Ad. at 253.

17 See, e.g., United States v. Chibbaro, 361 F.2d 365 (3d Cir. 1966); United States ex rel. Stovall v. Denno, 355 F.2d 731 (2d Cir.), cert. granted, 384 U.S. 1000 (1966); Kennedy v. United States, 353 F.2d 462 (D.C. Cir. 1965); Caldwell v. Únited States, 338 F.2d 385 (8th Cir. 1964), cert. denied, 380 U.S. 984 (1965); Blackford v. United States, 247 F.2d 745 (9th Cir. 1957), cert. denied, 356 U.S. 914 (1958); Brateher v. United States, 149 F.2d 742 (4th Cir.), cert. denied, 328 U.S. 885 (1945); Swingle v. United States, 151 F.2d 512 (10th Cir. 1945); Hartzell v. United States, 72 F.2d 569 (8th Cir.
} 
type of evidence, which subsumed a defendant's revelations of knowledge, was protected; while the latter category, involving merely physical evidence, was not within the privilege. Accordingly, the federal cases have held that line-up ${ }^{48}$ and individual identifications, ${ }^{49}$ physical examinations, ${ }^{50}$ fingerprints, ${ }^{51}$ voice identifications, ${ }^{52}$ and writing exemplars ${ }^{53}$ involve eliciting real or non-testimonial evidence' from an accused and thus in no way contravene the fifth amendment..$^{54}$

The relatively few federal cases dealing with evidence taken from within the accused's body have reiterated the "real-testimonial" distinction. ${ }^{55}$ In Blackford $v$. United States, ${ }^{56}$ for example, the Ninth

1934); United States v. Kelley, 55 F.2d 67 (2d Cir. 1932); 8 Wigmore \$2265, at 386; cf. Palmer v. Peyton, 359 F.2d 199 (4th Cir. 1966), 19 Stan. L. Rev. 479 (1967). But see Wade v. United States, 358 F.2d 557 (5th Cir.), cert. granted, 385 U.S. 811 (1966). See generally 8 WIGMORE $\$ 2265$.

${ }^{48}$ Rigney v. Hendrick, 355 F.2d 710 (3d Cir. 1965), cert. denied, 384 U.S. 975 (1966). But see Wade v. United States, supra note 47.

to United States ex rel. Stovall v. Denno, 355 F.2d 731 (2d Cir.), cert. granted, 384 U.S. 1000 (1966).

${ }^{60}$ McFarland v. United States, 150 F.2d 593 (D.C. Cir. 1945), cert. denied, 326 U.S. 788 (1946).

61 United States v. Kelley, 55 F.2d 67 (2d Cir. 1932).

s2 United States v. Chibbaro, 361 F.2d 365 (3d Cir. 1966).

cs Hartzell v. United States, 72 F.2d 569 (8th Cir. 1934).

* See generally Orfield, The Privilege Against Self-Incrimination in Federal Cases, 25 U. PITT. L. REv. 503 (1964).

All states, operating independently of federal constitutional mandates, have recognized the privilege against self-incrimination. The great majority have viewed the privilege in terms of Wigmore's "testimonial" criterion. See, e.g., State v. Berg, 76 Ariz. 96, 259 P.2d 261 (1953); Commonwealth v. Musto, 348 Pa. 300,35 A.2d 307 (1944); 8 WIGMORE $\$ 2265$.

Several jurisdictions have adopted and then seemingly discarded an extension of the testimonial or communicative rule, holding that the privilege applies to all compelled acts which involve the accused's active participation in creating the evidence. Compare Apodaca v. State, 140 Tex. Crim. 593, 146 S.W.2d 381 (1940), with Skaggs v. State, 167 Tex. Crim. 254, 319 S.W.2d 310 (1958). Compare State v. Taylor, 213 S.C. 330, 49 S.E.2d 289 (1948); People v. Graves, 64 Cal. 2d 208, 211, 411 P.2d 114, 116, 49 Cal. Rptr. 386, 388 (dissenting opinion), cert. denied, 385 U.S. 883 (1966). At least one state has relied upon the accuracy of the identification procedure involved, namely fingerprints, to determine whether the privilege should apply. Lester v. State, 416 P.2d 52 (Okla. Crim. App. 1966).

¿v Insofar as intracorporeal searches are concerned, nearly all states allow the extraction of blood samples to determine intoxication. See Note, 18 STAN. L. REv. 243 n.3 (1965); see also Slough \& Wilson, Alcohol and the Motorist: Practical and Legal Problems of Chemical Testing, 44 MINN. L. Rev. 673 (1960). When faced with a claim of self-incrimination, the state courts have denied applicability of the privilege to such tests on the basis of the real-testimonial distinction. See, e.g., People v. Haeussler, $41 \mathrm{Cal}$. 2d 252, 260 P.2d 8 (1953), cert. denied, 347 U.S. 931 (1954); State v. Blair, 45 N.J. 43, 211 A.2d 196 (1965); State v. Cram, 176 Ore. 577, 160 P.2d 283 (1945); Commonwealth v. Tanchyn, $200 \mathrm{~Pa}$. Super. 148, 188 A.2d 824, cert. denied, 375 U.S. 866 (1963).

s8 247 F.2d 745 (9th Cir. 1957), cert. denied, 356 U.S. 914 (1958). 
Circuit held that the introduction in evidence of narcotics which had been forcibly extracted from the accused's rectum did not violate his privilege against self-incrimination, since he had not been compelled to testify against himself. ${ }^{57}$

\section{SEARCH AND SEIZURE}

The fourth amendment provides that a minimal standard of "reasonableness" must be met in the exercise of governmental power to invade the "person, houses, papers, and effects" of its citizens. ${ }^{58}$ While "reasonableness" is necessarily a function of all the circumstances of a particular situation, ${ }^{59}$ the decisions of the Supreme Court have emphasized four factors in analyzing the reasonableness of any search and seizure: ${ }^{60}$ the "probable cause" motivating the search, its scope ${ }^{62}$ the search procedures utilized ${ }^{63}$ and the type of evidence sought. ${ }^{64}$ It is settled that a criminal suspect may be searched with-

${ }^{87} 247$ F.2d at 754. The Blackford court adopted Wigmore's view of the privilcge, see note 33 supra and accompanying text, stating that the privilege protected only against extracting a confession from the accused's own lips. 247 F.2d at 754.

${ }_{88}$ The primary purpose of the fourth amendment was to prevent a repetition of the "general" warrants which had so incensed British citizens. These warrants permitted general searches of homes and warehouses without a showing prior to issuance that the government had reasonable grounds to believe that specific evidence would be found. Davis v. United States, 328 U.S. 582, 603.06 (1946) (Frankfurter, J., dissenting). The colonists experienced this form of axbitrary governmental invasion under the infamous writs of assistance, which were nonreturnable and authorized customs agents to enter homes, shops, and warehouses in search of contraband without probable cause that such evidence would be procured. LAsson, THE History AND DEVELOPMENT OF THE FOURTh AMENDMENT 23.106 (1939) [hereinafter cited as LAsson]. See generally Barrett, Personal Rights, Property Rights, and the Fourth Amendment, 1960 Sup. CT. REv. 46; Kamisar, Wolf and Lustig Ten Years Later: Illegal State Evidence in State and Federal Courts, 43 MiNN. L. REv. 1083, 1084-1129 (1959); Reynard, Freedom from Unreasonable Search and Seizure-A Second Class Constitutional Right?, 25 IND. L.J. 259 (1950); Way, Increasing Scope of Search Incidental to Arrest, 1959 WASH. U.L.Q. 261; Comment, 25 OHo ST. L.J. 538 (1964); Comment, 28 U. ChI. L. Rev. 664 (1961).

${ }^{80}$ E.g., Go-Bart Importing Co. v. United States, 282 U.S. 344, 357-58 (1931); Chapman v. United States, 365 U.S. 610, 618 (1961) (Frankfurter, J., concurring).

${ }^{\circ 0}$ See generally Comment, 25 OHio Sr. L.J. 538, 543-74 (1964).

33 E.g., Ker v. California, 374 U.S. 23 (1963); Draper v. United States, 358 U.S. 307 (1959); Brinegar v. Unitéd States, 338 U.S. 160 (1949); Agnello v. United States, 269 U.S. 20 (1925).

${ }^{62}$ E.g., Abel v. United States, 362 U.S. 217, 235-39 (1960); sec Kremen v. United States, 353 U.S. 346 (1957). But see Harris v. United States, 331 U.S. 145 (1947). See generally LAsson 120; Way, supra note 58; Comment, 25 OHo Sr. L.J. 538 (1964). ${ }^{3}$ Compare Lopez v. United States, 373 U.S. 427 (1963), with Silverman v. Unitcd States, 365 U.S. 505 (1961). Compare Breithaupt v. Abram, 352 U.S. 432 (1957), with Rochin v. California, 342 U.S. 165 (1952).

o4 Abel v. United States, 362 U.S. 217, 234-35 (1960); Harris v. United States, 331 U.S. 145, 154 (1947); United States v. Lefkowitz, 285 U.S. 452, 463.66 (1932); Marron v. 
out a warrant so long as the search is incident to a lawful arrest for probable cause. ${ }^{65}$ This exception to the general rule requiring a warrant for searches is based on the assumption that without such a search the accused would be free to destroy evidence in his possession or to use concealed weapons against the arresting officer. ${ }^{66}$

The permissible scope of searches incident to a lawful arrest has in the past included at least the surface of a suspect's body and the material thereon. ${ }^{67}$ It has been unclear, however, whether the permissible "scope" of the search varies as a function of the object being sought..$^{68}$ Blackford $v$. United States, ${ }^{69}$ a case involving facts analo-

United States, 275 U.S. 192, 199 (1927); Gouled v. United States, 255 U.S. 298, 308-09 (1921).

or See, e.g., Ker v. California, 374 U.S. 23, 34-35 (1963); Henry v. United States, 361 U.S. 98,102 (1961); Draper v. United States, 358 U.S. 307, $310-11$ (1959); United States v. Rabinowitz, 339 U.S. 56, $72-73$ (1950) (Frankfurter, J., dissenting); Brinegar v. United States, 338 U.S. 160, I75-76 (1949); Johnson v. United States, 333 U.S. 10, 15-16 (1948); Agnello v. United States, 269 U.S. 20, 30 (1925); LAsson 123-26; Note, 31 Albany L. Rev. 177 (1967); Comment, 25 Ohio St. L.J. 538, 543-62 (1964).

Probable cause for an arrest and search incident thereto exists when "the facts and circumstances within [the arresting officer's] knowledge and of which [he has] reasonably trustrvorthy information [are] sufficient in themselves to warrant a man of reasonable caution in the belief that' an offense has been or is being committed." Brinegar v. United States, 338 U.S. 160, $175-76$ (1949) (quoting from Carroll v. United States, 267 U.S. 132,162 (1925).

Mere suspicion of criminahty will not suffice for an ordinary search. See, e.g., Aguilar v. Texas, 378 U.S. 108, $112-16$ (1964); Wong Sun v. United States, 371 U.S. 471, 479-84 (1963); Byars v. United States, 273 U.S. 28, 29 (1927). However, Congress has indicated, through its power to regulate unlawful importation of goods into the United States, that mere suspicion is sufficient for the search of a person thought to be smuggling. Alexander v. United States, 362 F.2d 379 (9th Cir. 1966), and cases cited therein. See generally Kamisar, The Wiretapping-Eavesdropping Problem: $A$ Professor's View, 44 MinN. L. Rev. 891, 933-34 (1960). The lower courts have held that this mere-suspicion standard is sufficient to allow entry into the body in search of contraband. See Blefare v. United States, 362 F.2d 870, 874-76 (9th Cir. 1966); authorities cited note 3 supra. The Supreme Court has given some support to this view by holding that a lesser degree of probable cause will be demanded in a general border search than in the search of houses, papers, or effects. See Preston v. United States, 376 U.S. 364 (1964); Carroll v. United States, 267 U.S. 132 (1925); cf. United States v. Di Re, 332 U.S. 581, 585 (1948).

For the effect of Schmerber upon a decision involving smuggling through the use of a body cavity, see Rivas v. United States, 368 F.2d 703, 710-11 (9th Cir. 1966); note 110 infra.

${ }^{\circ 0}$ Abel v. United States, 362 U.S. 217, 236 (1960); Marron v. United States, 275 U.S. 192, 199 (1927); Agnello v. United Statès, 269 U.S. 20, 30 (1925); People v. Chiagles, 237 N.Y. 193, 142 N.E. 583 (1923) (Cardozo, J.).

${ }^{07}$ Aguilar v. Texas, 378 U.S. 108 (1964); Preston v. United States, 376 U.S. 364 (1964); Abel v. United States, 362 U.S. 217 (1960); Agnello v. United States, 269 U.S. 20 (1925); Weeks v. United States, 232 U.S. 383 (1914); People v. Chiagles, supra note 66.

${ }^{\circ \theta}$ At least three commentators intimated that blood tests might be held unconstitutronal because of the Court's increasingly liberal view of the scope of the Bill of 
gous to the withdrawal of blood samples, indicated that the scope of a search was limited only to the extent that the place of secretion was accessible by reasonable methods of search: "if the culprit is "caught with the goods'" the Government may seize that evidence from wherever secreted. ${ }^{70}$

Breithaupt $\boldsymbol{v}$. Abram, ${ }^{\mathbf{7 1}}$ used for analogy in the Blackford court's analysis of scope limitations, also provides analogous precedent for determining what methods may reasonably be employed to obtain evidence from within the body. The Blackford court utilized the fourteenth amendment due process test of Breithaupt ${ }^{72}$ as the preliminary basis for determining the reasonableness of the means of search under fourth amendment criteria. ${ }^{73}$

Perhaps the most stringent and confusing limitation on governmental search and seizure is the so-called "mere evidence" rule, according to which a search may never be instituted to seek anything but contraband or fruits or instrumentalities of a crime within the accused's possession. ${ }^{74}$ This rule was first formally articulated in Gouled $v$. United States, ${ }^{75}$ wherein the Court considered the allegation that a defendant's private papers could not properly be sought under a search warrant. The Gouled Court held that such a search was unreasonable unless the Government could assert a "primary right" in the materials sought. Their seizure and introduction into evidence was otherwise no different from a requirement that the

Rights. See Ruffin, supra note 21, at 16-20; Note, 41 Notre Dame LAw. 1009, 1013.14 (1966); Note, 18 STAN. L. REv. 243, 256 (1965). However, others felt that a Breithaupt situation would result in affirmance of the validity of blood tests. See Note, i7 Hastings L.J. 139 (1965). See generally Karst, Legislative Facts in Constitutional Litigation, 1960 SuP. CT. REv. 75.

${ }^{\circ} 247$ F.2d 745 (9th Cir. 1957), cert. denied, 356 U.S. 914 (1958). See notes 56.57 supra and accompanying text.

zo 247 F.2d at 749. See generally Way, supra note 58.

71352 U.S. 432 (1957).

${ }^{72}$ See notes 27-29 supra and accompanying text.

73247 F.2d at 750-52. The Ninth Circuit in Blackford noted that the reasonableness criterion for the fourth amendment is stricter than the due process test of Rochin $v$. California, 342 U.S. 165 (1952). See notes 23-25 supra and accompanying text. Thus, the court stated that "there may be, we conceive, conduct which, while unreasonable is not so unconscionable that it "shocks the conscience' or 'offend[s] a sense of justice.'" 247 F.2d at 750. Nevertheless, continued the court, the Supreme Court's decisions in Rochin and Breithaupt "furnish the most helpful judicial guide" in determining the reasonableness of methods used to procure evidence from within the body. Id. at 751 .

However, other cases have treated the fourth amendment and due process standards as equivalents. See Blefare v. United States, 362 F.2d 870, 875-76 (9th Cir. 1966).

76 See cases cited note 64 suprá.

25255 U.S. 298 (1921). 


\section{defendant himself produce the evidence in violation of his fifth} amendment privilege. ${ }^{76}$ The Supreme Court has since indicated that

70 Id. at 311. The mere evidence rule is derived from the holding in Boyd v. United States, 116 U.S. 616 (1886). See notes 4-6 supra and accompanying text. That case posited an "intimate relationship" between the fourth and fifth amendments to the extent that a search for and seizure of certain evidence may be no different from requiring an accused to testify against himself thus violating his fifth amendment privilege against self-incrimination. Since the search for such inculpatory material is thereby rendered unreasonable, a violation of the fourth amendment is also established. The Court did, however, distinguish the situation where the Government had a superior right of possession-for example, in the case of stolen goods, contraband, and the instrumentalities of the crime. 116 U.S. at $623,633$.

Thus the basis of the mere evidence rule was originally thought to be a property concept. However, the property theory fails to explain why police can seize evidence which belongs to the accused such as weapons or instrumentalities of crime. People v. Thayer, 63 Cal. 2d 635, 408 P.2d 108, 47 Cal. Rptr. 780 (1965) (Traynor, J.), cert. denied, 384 U.S. 908 (1966); Comment, 66 CoLuM. L. REv. 355, 362-63 (1966); Comment, 20 U. CHI. L. REv. 319, 323-24 (1953); cf. Jones v. United States, 362 U.S. 257, 265-66 (1960).

Other theories which have been utilized to explain the rule are based upon the fourth and fifth amendments. The fifth amendment rationale that the accused is forced to incriminate himself by being the unwilling source of his own conviction is applicable only in a situation where the individual is compelled to produce evidence against himself as in Boyd. See notes 92-94 infra; Comment, 66 Colum. L. Rev. 355, 362 (1966). However, in this instance the fifth amendment alone, without the aid of the "mere evidence" rule, is sufficient to prohibit the admission of such evidence. Comment, 20 U. ChI. L. REv. 319, 324-26 (1953); Comment, 13 U.C.L.A.L. REv. 857, 863-86 (1966). But see Note, 54 GEO. L.J. 593, 605-06 (1966).

The fourth amendment rationale is that the mere evidence rule serves to protect the privacy of the individual by keeping personal effects free from governmental scrutiny. This is not an acceptable explanation of the rule, however, because it has failed to limit the scope of searches incident to arrests. Comment, 66 ColUM. L. REv. 355, 367-68 \& nn. 78-85 (1966). See also Note, 54 GEO. L.J. 593, 598, 605 (1966); Comment, 13 U.C.L.A.L. REv. 857, 859-63 (1966). One of the major reasons for this failure is that frequently the police are not able to determine whether the evidence will be considered to be "mere" evidence or an instrumentality of the crime and therefore admissible. See Marron v. United States, 275 U.S. 192, 199 (1927) (utility bills held admissible as "convenient" and "closely related" evidence of crime).

The rule has been criticized by the great majority of commentators. See 8 WIGMORE \$2184 (a); Kamisar, Public Safety $v$. Individual Liberties: Some "Facts" and "Theories," 53 J. CRIM. L., C. \& P.S. 171, 177 (1962); Kaplan, Search and Seizure: A No Man's Land in the Criminal Law, 49 CALIF. L. REv. 474, 477-79 (1961); Shellow, The Cantinuing Vitality of the Gouled Rule: The Search for and Seizure of Evidence, 48 MARQ. L. REV. 172, 175 (1964); Traynor, Mapp v. Ohio at Large in the Fifty States, 1962 Duke L.J. 319, 330-31; Comment, 66 Colum. L. Rev. 355, 359, 370 (1960); Comment, 25 OHo ST. L.J. 538, 556-57 (1964).

Few commentators have supported the rule, and then only with qualifications. See Ruffin, Intoxication Tests and the Bill of Rights: $A$ New Look, 2 GALIF. WWEstern L. REv. 1, 9-16 (1966); Comment, 13 U.C.L.A.L. REv. 857, 861-63 (1966); Note, 54 GEO. L.J. 593, 605-06 (1966).

Three state courts have recently repudiated the mere evidence rule, holding that it is not a constitutional mandate (at least upon the property theory) but rather a federal rule of evidence promulgated under the Supreme Court's supervisory powers. See People v. Thayer, supra; State v. Bisaccia, 45 N.J. 504, 213 A.2d 185 (1965); People v. 
the mere evidence rule is applicable to the search of a person incident to lawful arrest. ${ }^{77}$

Since the mere evidence rule as an application of the fourth and fifth amendments, in theory, denies admissibility to evidence other than instrumentalities, contraband, or stolen property-no matter how relevant ${ }^{78}$-lower courts have been ambivalent in their interpretation and manipulation of it. Some of the lower courts have applied the rule in its strictest form. ${ }^{79}$ On the other hand, at least one court has gone to the extreme of finding an accused's shoes to be the "instrumentalities" of a crime in order to avoid the prohibitions of the rule and admit relevant material in evidence. ${ }^{80}$ Other courts have recognized the futility of attempting to classify evidence in this manner and have held relevant evidence admissible notwithstanding the rule. ${ }^{81}$

Carroll, 38 Misc. 2d 630, 238 N.Y.S.2d 640 (Sup. Ct. 1963). Contra, Hayden v. Warden, 366 F.2d 647 (4th Cir.) (rule a constitutional mandate), cert. granted, 385 U.S. 926 (1966).

However, even if the mere evidence rule is found to be without a constitutional basis, it would still be applicable to federal law enforcement in the form of FED. R. CRIM. P. 41 (b), which would still be in effect through the Supreme Court's supervisory powers. See generally Note, 54 GEo. L.J. 593 (1966).

${ }^{77}$ Note, 54 GEo. L.J. 593, 616 (1966). In United States v. Lefkowitz, 285 U.S. 452, 464 (1932), the Court denied admissibility to bills and ledgers recording a crime, on the grounds that the search was exploratory and general, but added, in dictum, that the authority to search incident to arrest was no greater than that to search under a warrant. Fifteen years later, Harris v. United States, 331 U.S. 145, 154 (1947), upheld a search incident to a valid arrest which resulted in discovery of incriminatory matcrial in his home, the Court stating, again in dictum, that "mere evidence" could not be seized incident to a lawful arrest.

But see Margeson v. United States, 361 F.2d 327 (1st Cir.), cert. denied, 385 U.S. 830 (1966), holding that it was unnecessary to reach the question of whether shoes taken from a robber were instrumentalities of the crime since they were relevant evidence seized incident to a lawful arrest. Id. at $328 \&$ n.8. The First Circuit thus upheld the district court's contention that the mere evidence rule had never 'been applied to searches incident to a lawful arrest. United States v. Margeson, 246 F. Supp. 219, 224 (D. Me. 1965).

${ }^{78}$ E.g., Gouled v. United States, 255 U.S. 298 (1921); Hayden v. Warden, 363 F.2d 647 (4th Cir.), cert. granted, 385 U.S. 926 (1966); United States v. Loft on Sixth Floor, 182 F. Supp. 322 (S.D.N.Y. 1960). See People v. Thayer, 63 Cal. 2d 635, 408 P.2d 108, 47 Cal. Rptr. 781 (1965) (Traynor, J.), cert. denied, 384 U.S. 908 (1966).

7o Hayden v. Warden, supra note 78; Takahashi v. United States, 143 F.2d 118 (9th Cir. 1944); United States v. Stern, 225 F. Supp. 187 (S.D.N.Y. 1964); United States v. Loft on Sixth Floor, supra note 78.

${ }^{80}$ United States v. Guido, 251 F.2d 1 (7th Cir.), cert. denied, 356 U.S. 950 (1958).

81 See Marron v. United States, 275 U.S. 192 (1927); Golliher v. United States, 362 F.2d 594 (8th Cir. 1966); United States v. Boyette, 299 F.2d 92 (4th Cir.), cert. denied, 369 U.S. 844 (1962); King v. Pinto, 256 F. Supp. 522 (D.N.J. 1966); United States v. Pardo-Bolland, 229 F. Supp. 473 (S.D.N.Y. 1964); State v. Raymond, 142 N.W.2d 444 (Iowa 1966); State v. Bisaccia, 45 N.J. 504, 213 A.2d 185 (1965). 


\section{Schmerber v. California}

In Schmerber $v$. California, ${ }^{82}$ the Court was faced with the problem of explicating the relationship between the fourth and fifth amendments as set forth by the Boyd and Gouled cases. In resolving this difficulty, Schmerber modified Boyd and Gouled to the extent that it holds not that the fourth and fifth amendments are equivalent ${ }^{83}$ in their protections but rather that the fifth amendment limits that which may reasonably be sought and seized under the fourth. ${ }^{84}$ By carefully defining the scope of the fifth amendment, the Court obviated the mere evidence rule.

The major difficulty faced by the Court with regard to the fifth amendment lay in properly defining "self-incrimination" so as to avoid the unrealistic strictures of a "from the accused's own mouth"85 formula and the equally unrealistic liberality of the approach suggested by the petitioner in Holt $v$. United States. ${ }^{86}$ The Court's articulation of this definition carefully delineated the history and aims of the privilege and noted that its coverage does not fully encompass the "complex of values it seeks to preserve."87 Thus, while the broad aims of the privilege may be said to involve the protection of the privacy and integrity of the individual, 88 the Court pointed out that history and precedent confined its protection to the situation in which the state seeks to acquire evidence by "the simple expedient

82384 U.S. 757 (1966).*

88 Gouled v. United States, 255 U.S. 298, 306 (1921); Boyd v. United States, 116 U.S. 616,633 (1886). See notes 102-08 infra and accompanying text.

84 Conversely, the fourth amendment is a limitation upon the extent and methods which the Government may employ in securing evidence admissible under the fifth. This delineation of the relationship between the two amendments may be a step toward what McNaughton states is required "surgery" for fifth amendment applicability. In his view, the fifth should be a "complement" of probable cause, that is, the accused should not be forced to provide the first evidence against himself. But if probable cause does exist, then the accused should be subject to relevant inquiry, even in judicial proceedings. See McNaughton, supra note 35, at 154. Compare, however, Mr. Justice Fortas' view that the fifth amendment privilege is not subject to defeasance by a showing of probable cause. Fortas, supra note 34 , at 99.

85384 U.S. at 763 n.7. See notes $47-54$ supra and accompanying text.

${ }^{80} 218$ U.S. 245, 252-53 (1910). See 384 U.S. at 761 n.5; notes $42-45$ supra and accompanying text.

${ }^{87} 384$ U.S. at 762.

88 See ibid. The "intimate relation" of the fourth and fifth amendments is a result of the fact that both protect the privacy of the individual as a source of evidence and the fifth amendment indicates one aspect of privacy which is to be protected under the fourth. Boyd v. United States, 116 U.S. 616, 629 (1886); Comment, 13 U.C.L.A.L. REv. 857-59 (1966). 
of compelling it from [the accused's] ... mouth." 80 By generalizing this statement from strictly oral to all communicative acts, the Court arrived at a limited expansion of self-incrimination: an act, communicative in nature, performed by the accused, which provides the prosecution with evidence against him. ${ }^{90}$

Though framed in terms of the doctrinaire approach characteristic of earlier cases, the Schmerber standard is more inclusive in that it shields the accused against being compelled to reveal either "oral" or "physical" evidence which communicates his knowledge or beliefs." The Court, in explicating the dimensions of "communication," reaffirmed the Boyd decision on the grounds that the production of private papers in response to a subpoena is a communicative response.92 By complying with the subpoena, the accused communicates the fact that he possesses the incriminatory material ${ }^{08}$ which is subsequently used against him.

\footnotetext{
80 384 U.S. at 762.

$9^{\circ}$ The Court held that the fifth amendment "relates only to acts on the part of the person to whom the privilege applies," and not "to evidence of acts non-communicative in nature as to the person asserting the privilege even though, as here [in forcing the 'donation' of blood] such acts are compelled to obtain the testimony of others...." Id. at 761 n.5. The result is a test very similar to Wigmore's conception of the mod. ern version of the privilege: "Unless some attempt is made to secure a communication ... upon which reliance is to be placed as involving the accused's consciousness of the facts and the operations of his mind in expressing it, the demand made npon him is not a testimonial one." 8 WIGMORE $\S 2265$, at 386. Consequently, although the Court specifically refuted Wigmore's historical "from the accused's own mouth" concept, 384 U.S. at $763 \mathrm{n} .7$, it necessarily utilized the Wigmore approach to the extent that the only things which can possibly be "communicated" are "consciousness of facts and operations of the mind."

Whether the privilege may be invoked therefore depends upon whether the act compelled is itself "communicative," that is, whether it reveals the accused's knowledge, beliefs, or emotional state. It was at this point that the majority and Mr. Justice Black parted company. In Mr. Justice Black's view, any evidence which "communicates" the guilt of one who is the unwilling source of that evidence is within the privilege. Id. at 775 (dissenting opinion). The Court took note of this criticism but held that the privilege applies only to communicative acts of the individual; otherwise all testimony concerning the "petitioner's condition" would fall within the privilege. Id. at 761 n.5.

${ }^{91}$ See id. at 764.

${ }_{22}$ Id. at 763.64.

${ }^{98}$ See Haywood v. United States, 268 Fed. 795, 802 (7th Cir. 1920); MAGUire, EvIDENCE OF GUILT 23 (1959); 8 WIGMORE $\$ 2264$, at 379; Comment, 13 U.C.L.A.L. REv. 857. 866-70 (1966).

The Boyd case involved a subpoena directing the accused to produce certain papers in court. Gouled applied the same reasoning as that employed in Boyd to facts in. volving a true search and seizure under a warrant. However, because the Gouled Court failed to distinguish between the accused's production of incriminatory evidence -an act which verifies the possession of inculpatory material-and the situation in which the accused is simply the unwilling source of evidence, the only explanation open
} 
The Schmerber majority also indicated that compelled lie-detector tests are violative of the fifth amendment because an effort is made "to prove guilt or innocence on the basis of physiological responses," which communicate or verify the accused's knowledge or beliefs concerning the crime in question..$^{95}$ On the other hand, the extraction of blood in Schmerber differs from compelling the production of papers and lie-detector tests because it does not force the accused himself to indicate his degree or knowledge of intoxication; ${ }^{96}$ the test does not depend upon his testimonial or communicative responses; and no reliance is placed upon his knowledge. ${ }^{97}$

to the Gouled Court for the result in Boyd was that the type of evidence produced there (mere evidence as opposed to the instrumentality of a crime) was constitutionally forbidden. See 255 U.S. at 308-10.

o\$ 384 U.S. at 764. One commentator states that it is not clear whether the invalidity of the lie-detector test is due to the compulsion exerted in forcing the accused to take the test or the fact that the "communicative" reactions are made in response to interrogation. Ruffin, supra note 76, at 38. However, it seems clear that the former explanation cannot be valid since there was compulsion to take the test in Schmerber. The point of differentiation between the two tests is that, in a liedetector test, the accused responds to interrogation with a revelation of knowledge; in the blood test, he simply is a source of evidence-there is no response, no communication of knowledge or belief. See generally Silving, Testing the Unconscious in Criminal Cases, 69 HaRv. L. Rev. 683 (1956).

os See generally Inbau, Lie Detection and Criminal Interrogation (3d ed. 1953).

${ }^{96}$ See 384 U.S. at 761 n.5; State v. Cram, 176 Ore. 577, 583, 160 P.2d 283, 286-87 (1945); Corwin, The Supreme Court's Construction of the Self-Incrimination Clause, 29 Mich. L. REv. 1, 13-18 (1930).

27 The Court indicated that fifth amendment problems could result both from an application or non-application of certain guilt-determining tests. If, for example, for reasons of religion, fear, or health, an accused confessed in lieu of undergoing the test, such a confession would be a communicative response to compulsion inherent in the state's threat to test. 384 U.S. at 765 n.9. The Court suggested that when the state seeks to introduce the accused's refusal to take a constitutionally sanctioned test into evidence, "general" fifth amendment principles would apply rather than the rule of Griffin v. California, 380 U.S. 609 (1965), which prohibits comment upon an accused's invocation of the privilege against self-incrimination. 384 U.S. at 765 n.9.

Since the Schmerber decision was handed down, People v. Sudduth, 52 Cal. Rptr. 377 (Dist. Ct. App.), aff'd - Cal. 2d -, 421 P.2d 401, 55 Cal. Rptr. 393 (1966) has suggested a disposition of an improper refusal to take a blood test. The district court distinguished the case of a hemophiliac's confession to avoid a blood test from that in which an accused offers to bribe an officer "not to test or to change the results of the test." 52 Cal. Rptr. at 381. The former, said the court, presents a compulsive situation and "any confession [the accused] . . . makes in order to avoid the test would be coerced." On the other hand, evidence of the attempted bribe would be an incriminating statement which would simply "permit the trier of facts to draw an inference of consciousness of guilt." Ibid. The distinction here would seem to be twofold: (1) in the first example, there is compulsion to confess; in the second there is no compulsion to bribe an officer; (2) in the first case there is a communication of the evidence of his guilt; but in the second, there is merely an inference of guilt.

As an alternative line of argument, an anology could be drawn to the "right of counsel" argument in Schmerber: where there is no constitutional right to refuse the 
While the fifth amendment standard espoused by the majority may produce untoward results, ${ }^{98}$ the Court nevertheless clearly rejected the notion that the amendment rendered an accused's body inviolate as a source of evidence. ${ }^{\text {g }}$ After defining the scope of the fifth amendment, the Court proceeded to delineate the relationship between the fourth and fifth amendments in the following terms:

test, the accused cannot invoke the fifth amendment to prohibit evidence of refusal to take the test. See 384 U.S. at 766; note 98 infra. In the case of the hemophilac, compulsion to take the test would be a violation of due process, but with refusal unprotected by constitutional safeguards the accused should acquire no privilege because of this refusal. See People v. Sudduth, 52 Cal. Rptr. at 382.

${ }^{98}$ The Schmerber standard is not adequate for the determination of fifth amendment applicability where evidence results from "implied verification." See Weintraub, Voice Identification, Writing Exemplars and the Privilege Against Self-Incrimination, 10 VAND. L. REv. 485, 503.08 (1957). For example, it may be presumed that in order for a witness' voice identification to be valid there must be a correlation between the voice spoken at the time of the crime and the impliedly normal voice spoken for identification purposes. According to Weintraub, since speech may be controlled by the accused "as a means of conveying ideas" any evidence resulting therefrom should be protected by the self-incrimination privilege. Id. at 506 .

In a recent decision, People v. Ellis, - Cal. 2d -, 421 P.2d 393, 55 Cal. Rptr. 385, reversing on other grounds $52 \mathrm{Cal}$. Rptr. 125 (Dist. Ct. App. 1966), the California Supreme Court determined that where such implied verification of normality exists, the "key issue . . . is the degree of reliance on the veracity of the accused." - Cal. 2d at -, 421 P.2d at 395 n.4, 55 Cal. Rptr. at 387 n.4. Mr. Chief Justice Traynor reasoned that since (1) it was unlikely that a false identification would occur because the accused accidentally disguised his voice to match that of the true criminal; and (2) since, in any event, the factor of disguise was insiguificant because "any attempt by a suspect to disguise his voice is apt to be detected readily by those persons who can compare the sample with his normal voice," id. at -, 421 P.2d at 395, 55 Cal. Rptr. at 387 , the "implied testimony" of the accused was not a siguificant factor in voice identification. Id. at $-\mathrm{n} .4,421$ P.2d at $395 \mathrm{n} .4,55$ Cal. Rptr. at 387 n.4. These may be fallacious criteria for determining the applicability of the privilege, however, because the ques. tion is not whether the accused is lying (disguising his voice) but whether he "communicates" either inculpatory or exculpatory information. See Schmerber v. California, 384 U.S. 757, 761 n.5 (1966). Schmerber, however, fails to determine whether that which communicates the status quo of a mutable characteristic, such as voice identification, is privileged. The case law strongly supports the admissibility of such evidence. See Fitzsimmons v. United States, 371 F.2d I040 (10th Cir. 1967); United States v. Chibbaro, 361 F.2d 365 (3d Cir. 1966); United States ex rel. Stovall v. Denno, 355 F.2d 731 (2d Cir.), cert. granted, 384 U.S. 1000 (1966); People v. Ellis, supra; People v. Graves, 64 Cal. 2d 208, 411 P.2d 114, 49 Cal. Rptr. 386 (1966), cert. denied, 385 U.S. 883 (1966); People v. Gilbert, 63 Cal. 2d 690, 408 P.2d 365, 47 Cal. Rptr. 909 (1965), cert. granted, 384 U.S. 985 (1966); State v. McKenna, 35 U.S.L. WEEk 2497 (N.J. Super. Ct. Feb. 3, 1967). But cf. Wade v. United States, 858 F.2d 557, 559 (5th Cir.), cert. granted, 385 U.S. 811 (1966).

On the other hand, if the same act-voice identification-were compelled for purposes of a voiceprint rather than witness identification, any implication of normality would be irrelevant, because even a disguised voice may be identified by voiceprints. See N.Y. Times, Apr. 12, 1966, p. 1, col. 2; id., Apr. 13, 1966, p. 55, col. 8; Newsweek, April 25, 1966, p. 30; Popular Science Monthly, Sept. 1965, p. 80. Arguably, therefore, the voice identification in this setting is outside the privilege.

${ }^{99} 384$ U.S. at 767. 
We begin with the assumption that once the privilege against self-incrimination has been found not to bar compelled intrusions into the body ... the Fourth Amendment's proper function is to restrain, not against all intrusions as such but against intrusions which are not justified under the circumstances or which are made in an improper manner. ${ }^{100}$

The clear implication of the Court's analysis is that the only limitation on the type of evidence which may be obtained from an accused is that evidence may not be seized which would be rendered inadmissible by the self-incrimination privilege. In this manner, the Court indirectly attempted to extricate the fourth and fifth amendments from the garbled relation imposed upon them by Gouled $v$. United States ${ }^{101}$ in the guise of the mere evidence rule. The Schmerber Court simply ignored the rule in the context of intracorporeal searches, ${ }^{102}$ substituting instead the "communicative" standard of the privilege against self-incrimination as determinative of the type of evidence which may be seized under the fourth amendment. ${ }^{103}$ If evidence taken from the body is not procured by compulsion against the testimonial or communicative capacities of the accused, its seizure is not unreasonable in this respect. Thus Schmerber's fifth amendment standard replaced the dogma of the mere evidence rule for the seizure of evidence from within the body. ${ }^{104}$

Furthermore, Schmerber indicates that the mere evidence rule may also be eviscerated insofar as search and seizure of houses, papers, and effects are concerned. The fifth amendment standard for intrusions into the body is much more permissive as to the types of evi-

\footnotetext{
${ }^{100} \mathrm{Id}$. at 768.

102 See notes 78-80 supra and accompanying text.

${ }^{102} 384$ U.S. at 768 (precedent "not instructive" in a search beyond the surface of

${ }^{108}$ The Court emphasized at two different points that in the first instance it is the self-incrimination clause which determines whether the body may be entered to obtain blood as evidence. See notes 99-100 supra and accompanying text.

${ }^{104}$ The fifth amendment basis of the mere evidence rule was destroyed when, in discussing self-incrimination, the Court held that "it could not be denied that in requiring petitioner to submit to the withdrawal and chemical analysis of his blood the State compelled him to submit to an attempt to discover evidence that might be used to prosecute him for a criminal offense." 384 U.S. at 761. (Emphasis added.) Gouled had indicated that the opposite was true. "[The state's powers] . . may not be used as a means of gaining access to a man's house or office and papers solely for the purpose of making search to secure evidence to be used against him a criminal or penal proceeding ...." 255 U.S. at 309.
} the body). 
dence which may be seized than is the mere evidence rule. For example, the search for and seizure of a diary containing the accused's admission of crime would be prohibited under the mere evidence rule $^{105}$ but not under an application of the self-incrimination standard, since the seizure would not involve a communicative act by the accused. ${ }^{108}$ Thus, if the mere evidence rule continues to be applied to extracorporeal searches and the fifth amendment standard to those intracorporeal in nature, an anomoly results: the accused's body is less sacrosanct than the home in which he lives. ${ }^{107}$ Because the Court placed such heavy emphasis upon the sanctity of the accused's body, ${ }^{108}$ it would be illogical to hold that this special privacy, requiring the greater protection, is guarded by the lesser standard. The resolution of the paradox requires the abandonment

\footnotetext{
205 United States v. Stern, 225 F. Supp. 187 (S.D.N.Y. 1964).

${ }^{108}$ In applying the fifth amendment the real question is whether papers equal knowledge or communication of knowledge, rather than physical evidence such as fingerprints, simply because they are verbalizations of thoughts. While it is arguable that a search warrant is compulsion for the terms of the fifth amendment, see Note, 54 Gro. L.J. 593, 605 (1966), nevertheless, if papers were seized, the mere act of seizure should involve no verification or communication of the accuscd's knowledge. See Schmerber v. California, 384 U.S. 757, 763-64 (1966). Compare Boyd v. United States, 116 U.S. 616 (1886), with Gouled v. United States, 255 U.S. 298, 309 (1921) ("There is no special sanctity in papers"). As an extreme example of the arbitraxy standards promoted by the mere evidence rule, if an individual wrote down the fact that he had committed a crime and the police seized it while searching under a warrant, such evidence could not be admissible. Sce note 105 supra. However, if the same piece of paper were swallowed by an accused and then compclled from his stomach without undue force, such evidence should be admissible against him. The accused himself would not have been forced to produce the evidence; the regurgitation would not have involved his testimonial capacities. See Macurre, Evidence of Guilt (1959). Cf. Blefare v. United States, 362 F.2d 870 (9th Cir. 1966). Thus if Schmerber is extended to its logical conclusion, the same item could be mere evidence when outside the hody but admissible if procured by an intracorporeal search.

It might be argued that the mere evidence rule serves a valid purpose in pro. tecting the accused's privacy by disallowing warrants in those cases where the only objective of the search is mere evidence. However, past experience has indicated that such a limitation would not restrict searches in practice. See Comment, 66 Colur. L. REv. 355, 367 (1966); see note 76 supra. Morcover, if this argument were valid it would appear anomalous that law enforcement officials could seize more under a search incident to arrest or in an emergency, where there is not the restraining factor of the independent magistrate, than they could under a warrant. Sce Note, 54 GEO. L.J. 593, 615-16 (1966).

${ }^{107}$ But see Barrett, supra note 58, at 49 (the Court has traditionally accorded greater protection to property rights than to personal rights).

${ }^{108}$ The Court stated that "the interests in human dignity and privacy which the Fourth Amendment protects forbid any such intrusions on the merc chance that desired evidence might be obtained. In the absence of a clear indication that in fact such evidence will be found, these fundamental human interests require law officcrs to suffer the risk that such evidence may disappear unless there is an immediate search." 384 U.S. at 769-70.
} 
of the mere evidence rule as a test for the reasonableness of a search and seizure in all cases.

In delineating the relationship between the fourth and fifth amendments, the Schmerber Court held that if the type of evidence seized is not excluded under the fifth amendment, the legality of the search and seizure then rests upon the existence of probable cause and the reasonableness of the methods utilized in securing the evidence. ${ }^{109}$

Although acknowledging that probable cause for arrest has been sufficient to permit a search of an accused's person, the Court held that the dignity and privacy of the accused demand that intrusions beyond the surface of the body be made only when there is a "clear indication" that the desired evidence will be secured.110 Even then, such a search will not be permitted, without a warrant, absent an emergency which threatens the "destruction of evidence," 111 such as the quick elimination of alcohol from the bloodstream.112 Thus, a stricter standard of probable cause is required

100384 U.S. at 768.

110384 U.S. at 769-70. (Emphasis added.) The Court had previously indicated that there may be varying degrees of the requisite probable cause depending upon the subject of the search. Cf. United States v. Di Re, 332 U.S. 581 (1948), which held that a search without arrest may be made of a vehicle but not of its occupants. The Court indicated that a different degree of probable cause may be required in searches of persons as opposed to personal effects or homes. Id. at 585 .

A more stringent probable cause requirement for penetrating the body surface is consistent with the Court's recent holdings: "[W]hen a search is based upon a magistrate's, rather than a police officer's, determination of probable cause, the reviewing courts will accept evidence of a less 'judicially competent or persuasive character than would have justified an officer in acting on his own without a warrant' . ..." Aguilar v. Texas, 378 U.S. 108, 111 (1964) (quoting from Jones v. United States, 362 U.S. 257, 270 (1960)).

Rivas v. United States, 368 F.2d 703 (9th Cir. 1966), held that "clear indication" occupies a niche somewhere between mere suspicion and probable cause insofar as border searches are concerned. Therefore, a registered narcotics user who is nervous, has recent needle marks, and is under drugs at the time of his entry into the United States, may reasonably be thought to be smuggling narcotics in body cavities and searched. Id. at 709-10. Schmerber suggests, however, that for intracorporeal searches, "clear indication" is a more stringent requirement than the simple "probable cause" requisite for extracorporeal searches. 384 U.S. at 769-70.

${ }_{111} I d$. at 770 (quoting from Preston v. United States, 376 U.S. 364, 367 (1964)). See also Note, 18 STAN. L. REV. 243 (1965).

The Court's statement that "search warrants are ordinarily required," 384 U.S. at 770, gives further support to the theory that the Court may be returning to its original position that a warrant is to be required whenever feasible. See Ruffin, supra note 76, at 39. Compare United States v. Rabinowitz, 339 U.S. 56 (1950), with Chapman v. United States, 365 U.S. 610 (1964), and Preston v. United States, 376 U.S. 364 (1964). But see Cooper v. California, 385 U.S. 610 (1967).

112 Both the probable cause for the arrest aud the "clear indication" for the search 
to enter the body in search of evidence than is needed to justify a search of the body surface or its surroundings.

Another factor considered in testing the constitutionality of the search and seizure in Schmerber was whether the methods utilized in extracting the blood sample met the fourth amendment criteria of reasonableness. ${ }^{113}$ Applying a test similar to the due process standard of Breithaupt $v$. Abram, ${ }^{114}$ the Court concluded that the blood analysis was reasonable because it is a commonplace, everyday occurrence involving minimal risk to the accused. ${ }^{115}$

Finally, the Court held that the circumstances under which the blood test is performed are relevant to a determination of the reasonableness of such a seizure. In Schmerber, the test was conducted by a physician in hospital surrounding; there was no risk of unqualified personnel or unsanitary conditions. ${ }^{116}$ Thus, concluded the Court, the standard of reasonableness was met and consequently there was no violation of the accused's rights under the fourth amendment.

Although the opinion thus rendered follows the logic of history and precedent, it nevertheless seems to reveal a change in the Court's fifth amendment philosophy by drawing a line beyond which the Court will not step in hedging police investigations. In Miranda $v$. Arizona, ${ }^{117}$ decided only one week before Schmerber, the Court formulated new rules for police interrogation seemingly upon the assumption that incriminating evidence revealed under questioning

in Schmerber were found in the smell of liquor upon the accused's breath and "bloodshot, watery, sort of glassy appearance" of petitioner's eyes. 384 U.S. at 769. But cf. Johnson v. United States, 333 U.S. 10 (1948) (opium fumes not sufficient as sole probable cause for searching defendant's room without a warrant).

118 See note 63 supra and accompanying text.

116 See 384 U.S. at 771-72; notes 27-28 supra and accompanying text.

${ }^{116}$ Petitioner had also refused to submit to a breathalizer test, which represents far less of an intrusion into the accused's person and functions with approximately equivalent accuracy. See Slough \& Wilson, Alcohol and the Motorist: Practical and Legal Problems of Chemical Testing, 44 MinN. L. REv. 673, 679 (1960). Although the Court expressly declined to decide whether the accused's test preference must be respected, 384 U.S. at 771, it would seem from dictum that since the petitioner did not object on "grounds of fear, concern for health, or religious scruple," ibid., his choice need not be respected unless an objection other than simple preference is asserted, even though one test requires entry into the body and the other does not. See also Karst, Legislative Facts in Constitutional Litigation, 1960 SUP. Cr. REv. 75, 82-83.

A recent California case has indicated that a petitioner's more active cooperation in a breathalizer test does not "communicate" any more than does his submission to a blood test as in Schmerber. People v. Sudduth, 52 Cal. Rptr. 377, 379-80 (Dist. Ct. App.), aff'd, - Cal. 2d -, 421 P.2d 401, 55 Cal. Rptr. 393 (1966).

110384 U.S. at $771-72$.

117384 U.S. 436 (1966). 
by one uninformed of his rights amounts to evidence achieved by compulsion.118 The Court thus expanded the concept of "compulsion" to include even the slightest amount of inquisitorial pressure. Having thus enlarged the ambit of compulsion to extreme limits in Miranda, the Court was forced to determine whether it should also amplify the substantive scope of the privilege. The majority in Schmerber did elect amplification but to a lesser degree than the Miranda majority had expanded the concept of compulsion.

However, the philosophies underlying Miranda and Schmerber are compatible if one accepts the statement made in both opinions that the object of the self-incrimination privilege is to secure a "fair State-individual balance."119 Such a balance cannot exist where the individual is ignorant of his right to silence and the state proceeds to take advantage of this fact-thus the rule in Miranda. Conversely, equilibrium is also destroyed if an accused may prevent state acquisition of evidence by the simple fact of its location inside his body-thus the holding of Schmerber.

\footnotetext{
${ }^{118}$ See id. at 457; United States v. Bell, 81 Fed. 830, 837-39 (C.C.W.D. Tenn. 1897).

${ }^{110}$ Schmerber v. California, 384 U.S. 757, 762 (1966); Miranda v. Arizona, 384 U.S. 436, 460 (1966).
} 